\title{
CHARACTERISTICS STUDY OF CONCRETE USING PLASTIC WASTE
}

\author{
D. RamaDevi, P. Vinodh Kumar, R. Vinodh Kumar \\ Civil Department, Meenakshi College of Engineering / Anna University, \\ Chennai, TamilNadu, India
}

\begin{abstract}
The objective of this research is to investigate the effectiveness of using waste plastic as a admixture in concrete constructions. The compressive and tensile strengths of various concrete specimens were tested to determine how the incorporation of recycled plastic as an admixture would affect the development of strength in the mixes. The project is about to use of plastic in civil construction. The components used are some types of plastics such as plastic cover and plastic bottles that are used in decoration, flooring, wall covering, waterproofing and mainly in constructions. Plastic use in construction that have shown same hope in terms of using plastic waste in building construction. i.e. plastic concrete. Plastic concrete mainly use plastic carry bags, disposable cups and PET bottles that are collected from garbage dumps as important ingredients of the construction materials. By using plastic waste as modifier, we can able to manage the quantity of cement and sand by their weight, hence decreasing the overall cost of construction. At $0.4 \%$ optimum modifier content, strength of modified concrete we found to see the times greater than the plain cement concrete. By the disposable plastics is the main source of plastic. So, this technology will result in lesser concrete repairs.
\end{abstract}

Keywords: Compressive strength, Flexural strength, Plastic, Split tensile strength, Plastic concrete.

\section{INTRODUCTION}

\subsection{GENERAL}

Concrete is the major construction materials, which are bonded together by cement and water. Aggregate plays the major role rather than cement. Aggregate includes sand and crushed stones/gravel. Use of these is a suitable substitute. Plastic which is generated in large quantities as waste doesn't have useful disposal till now. But it possesses properties that are required for viable replacement of coarse aggregate in concrete. Hence in this project we are aimed to study the effectiveness of plastic as substitute for coarse aggregate. Aggregate properties viz., specific gravity, water absorption, is to be conducted. Specimen to be prepared to conduct compressive, tensile and flexural strength of concrete for M25 grade with by plastic waste $(10 \%, 20 \%$, and $30 \%)$. These wastes (plastic) are almost non degradable in the natural environment even after a long period of exposure. So, plastic waste is now a serious environmental threat to the modern way of living. It is not feasible to use waste plastic for land filling, which require huge land space area and as well land loses its fertility. It also causes serious problems such as clogging in drainage system, wastage of resources and environmental pollution. In this consequence, big attention is being focused worldwide on the environment and safeguarding the natural resources through recycling of waste plastic materials in the recent years. It may appear to be valuable property as construction material Polymer aggregate is significantly lighter than natural aggregate and therefore it since corporation lowers the densities of their resulting concrete. This property can be used to develop lightweight concrete. Thus, utilization of waste plastic materials in concrete as aggregates may be considered one of the most feasible utilization may be one solution for the disposal problems. However, one of the main goals of sustainable solid waste management is to maximize the ability of its recycling and reusing waste materials. The present study focused on the use of plastic in concrete to find its characteristics.

\subsection{PLASTIC}

Plastic is material consisting of any of a wide range of synthetic or semi-synthetic organic compounds that are malleable and so can be molded into solid objects. Plastics are typically organic polymers of high molecular mass and often contain other substances. They are usually synthetic, most commonly derived from petrochemicals.

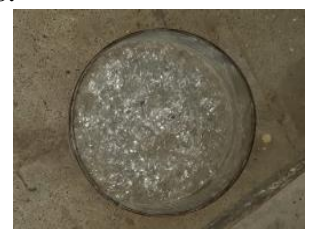

Fig 1 - Plastic used in this project 


\subsubsection{PROPERITIES OF PLASTIC}

The good characteristics of plastics are their versatility, light-ness, hardness, and resistant to chemicals, water and impact. It makes up much of the street side litter in urban and rural areas. It is rapidly filling up landfills as choking water bodies.

The objective of this paper is to investigate the key and positive characteristics of this product and the benefits obtained by using it in building. One can use solar bomb (bottle filled with bleaching powder solution) will be fitted on the roof for light source.

\subsubsection{USES OF PLASTIC}

Plastics are versatile, hygenic, lightweight, flexible and highly durable. Plastics are used for large numbers of packing items such as containers, bottles, drums, trays, boxes, cups and vending packaging, baby products and protection packaging.

\section{$1.3 \quad$ PLASTIC CONCRETE}

Concrete, one of the most common construction materials, requires a large amount of natural resources and energy. Natural resources used in concrete mixtures include lime stone, clay, sand, natural gravel, crushed stone, and water. With the rapid development in urban areas around the world in the recent years, our natural resources are depleting in an ever-increasing rate.

Therefore, it is necessary to develop a new material that consumes less natural resources and energy in order to make our construction methods more sustainable. Many efforts have been made to study the use of waste/by product materials, such as fly ash, slag, silica fume, and natural pozzolan, to replace Portland cement in a concrete mixture

\subsubsection{ADVANTAGES OF PLASTIC} CONCRETE

$\begin{array}{ll}- & \text { No corrosion } \\ - & \text { High strength } \\ - & \text { No electric conductivity } \\ - & \text { Non magnetic } \\ - & \text { Low weight }\end{array}$

1.3.2 DISADVANTAGES OF PLASTIC CONCRETE

$$
\begin{array}{ll}
- & \text { Higher price } \\
- & \text { Low modulus of elasticity } \\
- & \text { Limited experience } \\
- & \text { Long-term behaviour }
\end{array}
$$

\section{MATERIALS USED AND MIX PROPORTIONING}

\subsection{PROPERTIES OF MATERIALS}

The Different materials used in this project along with their properties are as follows:
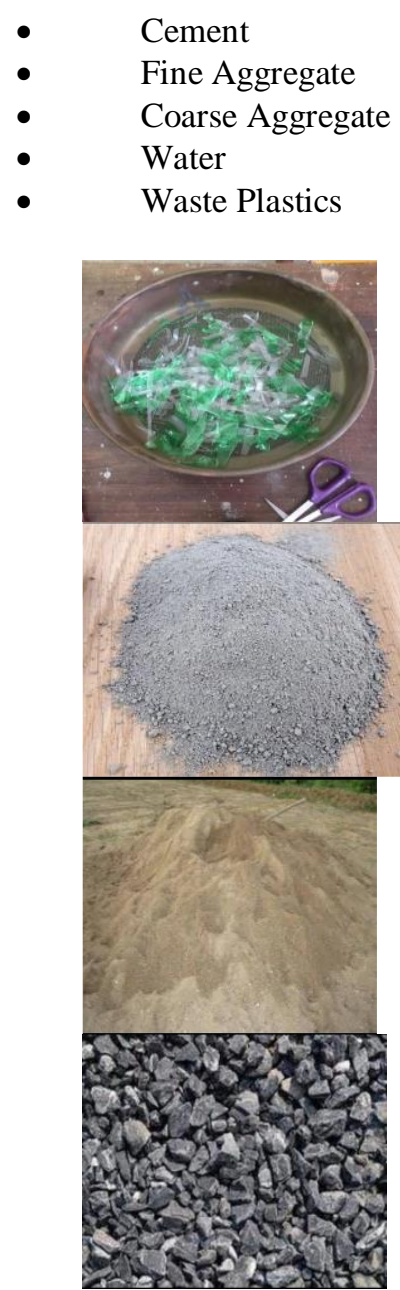

Fig 2 Plastic Cover, Cement, Sand and Gravel

\subsection{PROPORTIONING}

As per IS 10262: 2009, we design the mix ratio and it has been in the table 1 below.,

Table 1 Mix Design Proportions for M25

\begin{tabular}{|c|c|c|c|}
\hline $\begin{array}{c}\text { Water } \\
\text { (litres) }\end{array}$ & $\begin{array}{c}\text { Cement } \\
(\mathrm{Kg})\end{array}$ & $\begin{array}{c}\text { Fine } \\
\text { Aggregate } \\
(\mathrm{Kg})\end{array}$ & $\begin{array}{c}\text { Coarse } \\
\text { Aggregate } \\
(\mathrm{Kg})\end{array}$ \\
\hline 185.58 & 412.4 & 446.00 & 1320.94 \\
\hline
\end{tabular}

\subsection{SPECIMEN DETAILS}

The specimens used in this project work is been listed in the following table 2 .,

Table 2 Description of the specimens

\begin{tabular}{|c|c|l|l|}
\hline $\begin{array}{c}\text { Descrip } \\
\text { tion }\end{array}$ & $\begin{array}{c}\text { C } \\
\text { ub } \\
\text { e }\end{array}$ & $\begin{array}{c}\text { Cyli } \\
\text { nder }\end{array}$ & $\begin{array}{c}\text { Be } \\
\text { am }\end{array}$ \\
\hline $\begin{array}{c}\text { Withou } \\
\text { tplastic } \\
\text { (No.of } \\
\text { specim } \\
\text { en) }\end{array}$ & 3 & 3 & 3 \\
\hline \begin{tabular}{c} 
in \\
\hline
\end{tabular} & & & \\
\hline
\end{tabular}


International Journal of Engineering Applied Sciences and Technology, 2020

Vol. 4, Issue 12, ISSN No. 2455-2143, Pages 512-516

Published Online April 2020 in IJEAST (http://www.ijeast.com)

\begin{tabular}{|l|l|l|l|}
\hline $\begin{array}{c}\text { With } \\
\text { plastic } \\
\text { cover } \\
\text { (No.of } \\
\text { specim } \\
\text { en) }\end{array}$ & 3 & 3 & 3 \\
\hline $\begin{array}{c}\text { With } \\
\text { plastic } \\
\text { bottle } \\
\text { (No.of } \\
\text { specim } \\
\text { ens) }\end{array}$ & 3 & 3 & 3 \\
\hline
\end{tabular}

III. TESTING AND RESULTS

3.1 SLUMP CONE

The slump cone test details is shown below

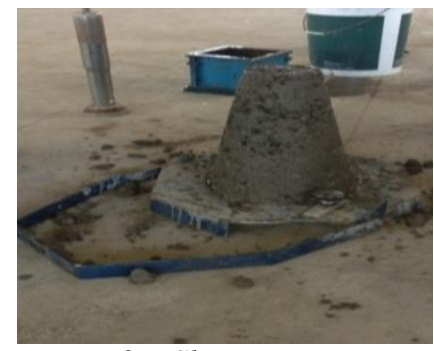

Fig 3 - Slump cone test

Table 3 Slump cone test

\begin{tabular}{|c|c|c|c|}
\hline $\begin{array}{c}\text { SF } \\
\text { in } \%\end{array}$ & $\begin{array}{c}\text { W/C } \\
\text { ratio }\end{array}$ & $\begin{array}{c}\text { Slump } \\
\text { value }(\mathrm{mm})\end{array}$ & Timing(seconds) \\
\hline 2 & 0.5 & 18.2 & 165 \\
\hline 5 & 0.55 & 43.0 & 143 \\
\hline 10 & 0.60 & 45 & 136 \\
\hline 20 & 0.65 & 58.4 & 105 \\
\hline 40 & 0.7 & 70 & 62 \\
\hline
\end{tabular}

\subsection{COMPRESSION TEST ON CUBES}

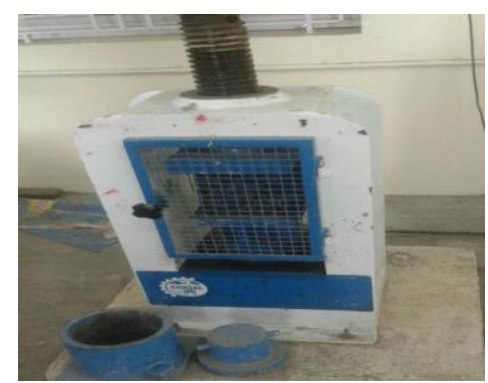

Fig 4 - Test on Compression strength for cubes
Table 4 Compression Strength of Concrete $\left(\mathrm{N} / \mathrm{mm}^{2}\right)$

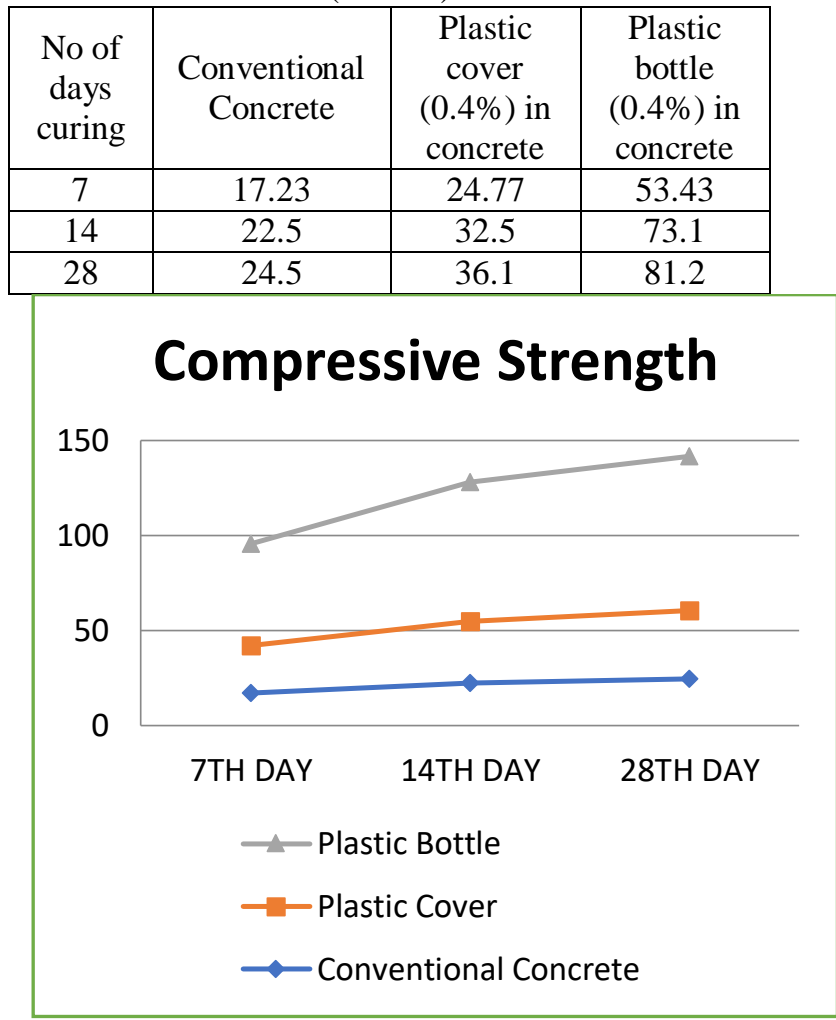

Fig 5-Compression strength test on cubes

\subsection{SPLIT TENSILE STRENGTH FOR CYLINDERS}

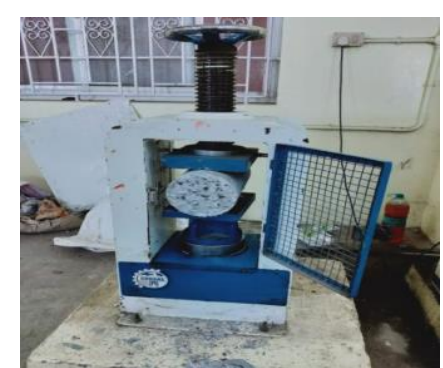

Fig 6-Split tensile test

Table 5 Split Tensile Test on Concrete $\left(\mathrm{N} / \mathrm{mm}^{2}\right)$

\begin{tabular}{|c|c|c|c|}
\hline $\begin{array}{c}\text { No of } \\
\text { days } \\
\text { curing }\end{array}$ & $\begin{array}{c}\text { Conventional } \\
\text { Concrete }\end{array}$ & $\begin{array}{c}\text { Plastic } \\
\text { cover in } \\
\text { concrete } \\
(0.4 \%)\end{array}$ & $\begin{array}{c}\text { Plastic } \\
\text { bottle } \\
(0.4 \%) \\
\text { in } \\
\text { concrete }\end{array}$ \\
\hline 7 & 6.18 & 7.8 & 11.05 \\
\hline 14 & 8 & 10.5 & 14.0 \\
\hline 28 & 9.5 & 12.0 & 17.0 \\
\hline
\end{tabular}


International Journal of Engineering Applied Sciences and Technology, 2020

Vol. 4, Issue 12, ISSN No. 2455-2143, Pages 512-516

Published Online April 2020 in IJEAST (http://www.ijeast.com)

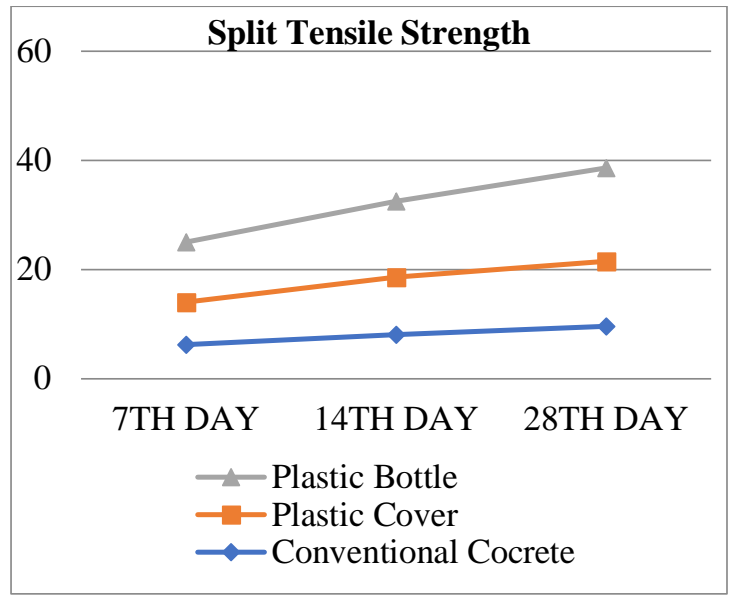

Fig 7-Split tensile strength test

\subsection{FLEXURAL STRENGTH ON PRISM}

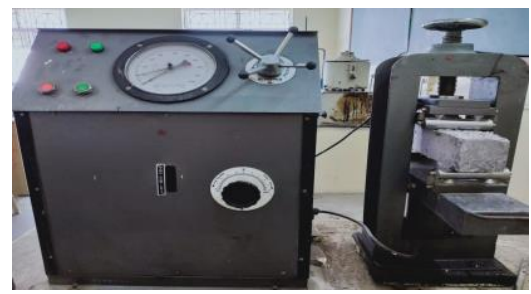

Fig 8 - Flexural strength

Table 6 Flexural Test on Concrete $\left(\mathrm{N} / \mathrm{mm}^{2}\right)$

\begin{tabular}{|c|c|c|c|}
\hline $\begin{array}{c}\text { No of } \\
\text { days } \\
\text { curing }\end{array}$ & $\begin{array}{c}\text { Conventional } \\
\text { Concrete }\end{array}$ & $\begin{array}{c}\text { Plastic } \\
\text { cover(0.4\%) } \\
\text { in concrete }\end{array}$ & $\begin{array}{c}\text { Plastic } \\
\text { bottle } \\
(0.4 \%) \\
\text { in } \\
\text { concrete }\end{array}$ \\
\hline 7 & 0.58 & 0.78 & 1.10 \\
\hline 14 & 0.7 & 0.95 & 1.5 \\
\hline 28 & 0.9 & 1.2 & 1.7 \\
\hline
\end{tabular}

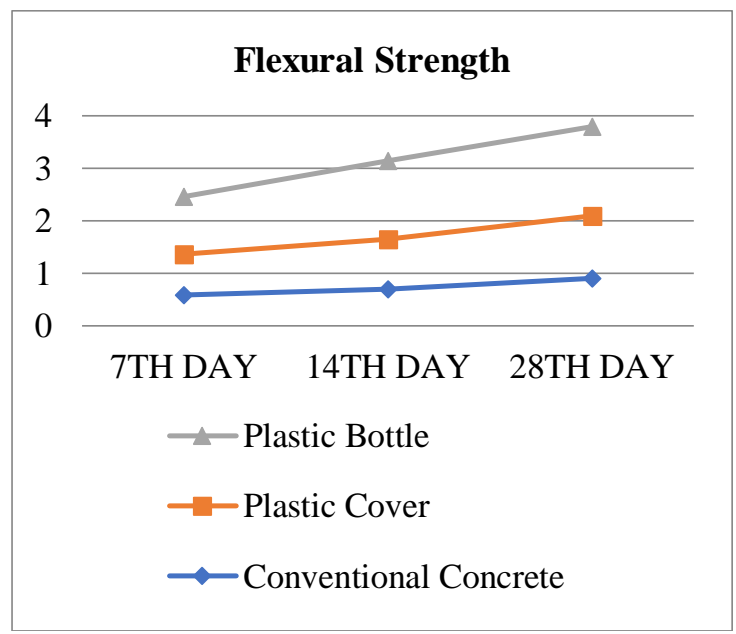

Fig 9 Flexural Test on Concrete

\section{CONCLUSION}

Based on the Experimental result following points are summarized with regard to effect of plastic on the properties of concrete

- Compressive strength of concrete is affected by addition of plastic pieces and it goes on decreasing as the percentage of plastic increases addition of $0.4 \%$ of plastic in concrete causes about $20 \%$ reduction in strength after 28 days curing.

- The splitting tensile strength observation shows the improvement of tensile strength of concrete. Addition of $0.4 \%$ of plastic improvement of strength recorded after that addition of strength of concrete decreases with addition of plastic.

- Thus it is conclude that the use plastic can be possible to increase the tensile strength of concrete.

- From the above discussion it is identified that the use of plastic can be possible to improve the properties of concrete which can act as a one of the plastic disposal method.

- Weight of the concrete, due to low density of plastics as compared to the density of fine aggregates. The product is useful in applications requiring non-bearing lightweight concrete such as concrete panel.

- It was observed in the result that the slump decreases with increase in the percentage of plastic, due to the fact that some particles are angular and others have non-uniform shapes resulting in less fluidity. The recycled plastic aggregates can be used up to $15 \%$ replacement of fine aggregates in the concrete mixture.

- The use of waste plastic in cement based composite can significantly reduced cost of construction through full or partial replacement of aggregates.

- The lightweight concrete can be used as floor tiles, roofing material, walling / partition material in storey buildings due to its light weight, non corrosive and weather proof capability.

- The used of waste plastics in constructions will grossly reduced rate of solid waste accumulation in the environment and income will be generated from its utilization.

- Finally, it was revealed during the study, that waste plastics are not good materials for improving the compressive strength of concrete. The LWC should not be used for load bearing where high compressive strength is required. 


\section{REFERENCES}

Journal Papers:

1. A Bhogayata, \& N K Arora, "Fresh and Strength Properties of Concrete Reinforced with Metalized Plastic Waste Fibers", Construction and Building Materials, vol. 146, pp. 455- 463. , 2017.

2. M Elzafraney, P Soroushian, \& M Deru, "Development of energy Efficient Concrete Buildings Using Recycled Plastic Aggregate", Journal of Architectural Engineering (C) ASCE, 2015.

3. Sarwe Khilesh, "Study of Strength Property of Concrete Using Waste Plastics and Steel Fibers", The International Journal of Engineering and Science, vol. 3, Issue 5, pp. 09-11. 2014

4. Mathew Praveen, Varghese Shibi, Paul Thomas, Varghese Eldho, "Recycled Plastic as Coarse Aggregate for Structural Concrete", International Journal of Innovative Research in Science, Engineering and Technology vol. 2, Issue 3. 2013

5. M Atul, Raghatate "Use of plastic in a concrete to improve its properties", International journal of Advance engineering Research and studies, pp. 1109-111. 2012

6. Patil S. Pramod, J.R Mali, Tapkire V Ganesh, R Koumavat, "Innovative Techniques of Waste Plastic Used in Concrete Mixture", International Journal of Research in Engineering and Technology. 2011

7. R L Ramesh, , K M Asharani, V C Katari Dhiraj, D S Sagar Pruthvi, R Sahana, "Recycled Plastics used as coarse aggregate for constructional concrete", SJB Institute of Technology, Bangalore 2009

8. P. Suganthy, Chandrasekar, Dinesh, P. K Kumar, Sathish, "Utilization of Pulverized Plastic in Cement Concrete as Fine Aggregate", ISSN: 2319-1163, vol. 2, Issue 6. 2013

9. Ghernouti Youcef, Rabehi Bahia, Safi Brahim, Chaid Rabah, "Use Of Recycled Plastic Bag Waste in the Concrete", Journal of International Scientific Publications: Materials, Methods and Technologies, vol. 8, ISSN 1314- 7269. 2013

10. Z. Ismail Zainab, \& Hashmi A. AL Enas. "Use of waste plastic in concrete mixture as aggregate replacement", Department of
Environmental Engineering, college of Engineering, University of Baghdad, Iraq. 